\title{
The Politics of Space: Kiobel v. Royal Dutch Petroleum
}

VB verfassungsblog.de/the-politics-of-space-kiobel-v-royal-dutch-petroleum-2/

Philip Liste Mo 22 Apr 2013

Law is a 'politics of space.' The last week's Supreme Court decision in 'Kiobel' significantly cuts the possibilities to sue human rights violators before courts in the United States, particularly when the relevant conduct occurred on the territory of a foreign sovereign. The decision builds upon a highly territorialized notion of law and points to what may be called a 'nationalization' of international law-with repercussions for the transnational law of public and private global governance. In the Kiobel case transnational oil corporations (Royal Dutch Petroleum/Shell) were accused of having aided and abetted in massive violations of human rights in Nigeria, including extrajudicial killings, crimes against humanities, and torture. The lawsuit was relying on the Alien Tort Statute (ATS) - a Judiciary Act enacted by the First Congress of the United States in 1789 - which is granting 'aliens' access to courts in the US for bringing tort claims basing on international law.

While human rights advocates criticize the decision as 'disappointment,' those speaking in the name of private business hail the judicial strengthening of the state. In fact, the decision points to an exclusion of private conduct beyond the jurisdictional boundaries of the Unites States from being adjudicated through state courts, even when massive violations of human rights are at issue. But at the same time this exclusion is achieved only by way of a perpetuation of nation-state boundaries - transnational private governance goes hand-in-hand with 'modern' nationstate practice.

While the Second Circuit had rejected the case for reasons of corporate liability (or non-liability, to be clear) the Supreme Court, after having heard oral arguments in February 2012, invited the parties for another round of 'rearguments,' focusing on the question of 'Whether and under what circumstances the Alien Tort Statute allows courts to recognize a cause of action for violations of the law of nations occurring within the territory of a sovereign other than the United States.' The issue at hand is thus somehow multidimensional. Who can be held responsible for what and where? Corporate liability is one dimension; substance-i.e. the question of what law to be applied to what kinds of events-is another. But the judges have now obviously decided to concentrate on a third dimension: space.

Coming into legal studies as kind of an 'outsider' (for being trained as an International Relations scholar), it is this spatial dimension of Kiobel that I would try to shed some light on. The recent opinion on Kiobel, besides eventually being a setback for human rights activism of the last decades, is but a contribution to a global 'politics of space.' Various fields in the social sciences have now been hit by what is often called 'spatial turn.' Some legal pluralists have taken up this impulse and even in the academic field of International Relations, where territoriality of the state was for long times taken as 'the' starting point of analysis, scholars are increasingly engaging in how territoriality and space are constructed, instead of being 'physically' given. The production of space, the demarcation of territorial and 'extraterritorial' legal practice, however, is setting the stage for how critical questions of public and private global governance are to be answered (or even posed). The demarcation of space is thus a precondition of any effective protection of human rights or freedom of private business, respectively. Although there is now an evolving body of literature scrutinizing politics of space in diverse locales, transnational human rights litigation is scarcely visible in this debate. So, let's take Kiobel as invitation for 'spatial' reflection.

'The question presented is whether and under what circumstances courts may recognize a cause of action under the Alien Tort Statute, for violations of the law of nations occurring within the territory of a sovereign other than the United States.' ( $p .1$ ) By putting the spotlight on territoriality the 'presumption against extraterritorial application' was immediately coming to the fore. 'That canon,' as the court's majority put it, 'provides that '[w]hen a statute gives no clear indication of an extraterritorial application, it has none [...].' (p. 4) In general, the rationale behind the presumption is to prevent interferences of US law into the sovereignty of foreign states. 
No doubt, the claims brought against Shell possess such extraterritorial reach. The question was thus whether there is something in the ATS rebutting the presumption. The majority's answer was: No. 'The ATS covers actions by aliens for violations of the law of nations, but that does not imply extraterritorial reach-such violations affecting aliens can occur either within or outside the United States.' (p. 7) Although being an interface between international law and domestic jurisprudence, the extraterritorial reach of the statute is not acknowledged. The ATS is thus interpreted as falling short of giving a 'clear indication of an extraterritorial application.' ( $p .4$ ) But is the absence of a 'clear indication' really that clear? Indeed, diverse objections could be put forward against such view. 'The ATS,' as Justice Breyer holds, 'was enacted with "foreign matters" in mind. The statute's text refers explicitly to "alien[s]," "treat[ies]," and "the law of nations." (p. 3) And by relying on the judgment in Sosa v. Alvarez-Machain, 542 U. S. 692, 732, he argues that 'at least one of the three kinds of activities that we found to fall within the statute's scope, namely piracy [...] normally takes place abroad.' (p. 4) Against the backdrop of the alternatives, the way chosen by the majority is hardly as self-evident as it is presented. Thus understood, the ATS although 'bringing international law home' (Harold Koh), falls short of transcending national territoriality. The Supreme Court's spatial politics, in other words, amounts to a 'nationalization' of international law.

\title{
Pirates, Incorporated
}

Since in the historical record of jurisprudence piracy was brought up as a possible target of ATS litigation (e.g. in Sosa), it is hardly doubted that pirates would indeed be liable under ATS. But what does this mean with respect to the problematique of human rights violations through private corporations? Is it conceivable that corporations are the today's pirates or do at least act like those? In the first of two oral argument sessions when corporate liability was on the agenda Justice Breyer confronted Kathleen M. Sullivan-she was pleading in front of the court for the respondent side-with a telling though somehow strange analogy: 'Do you think in the 18th century if they brought Pirates, Incorporated, and we get all their gold, and Blackbeard gets up and he says, oh, it isn't me; it's the corporation—do you think that they would have then said: Oh, I see, it's a corporation. Good-bye. Go home.' Sullivan's answer was this: 'Justice Breyer, yes, the corporation would not be liable.'

In the end, as already mentioned, liability was not the issue. But interestingly, piracy was. The reason for this is perhaps that the issue of piracy may be a potential Achilles' heel in the majority opinion. Piracy has an extraterritorial dimension. Acknowledging the right under international law to seize pirates in whatever place may not be compatible with saying that nothing in the ATS would point to rebutting the extraterritorial presumption-given that piracy is undoubtedly a convenient issue under this statute. Well, let's take a look:

\begin{abstract}
'Applying U. S. law to pirates, however, does not typically impose the sovereign will of the United States onto conduct occurring within the territorial jurisdiction of another sovereign [...]. Pirates [...] generally did not operate within any jurisdiction. [...] We do not think that the existence of a cause of action against them is a sufficient basis for concluding that other causes of action under the ATS reach conduct that does occur within the territory of another sovereign; pirates may well be a category unto themselves.' (pp. 10-11)
\end{abstract}

Putting it crudely, before pirates were given the chance to enter the stage, they became 'de-territorialized.' This localization of piracy within a 'non-space,' however, is hardly without any alternative. 'The majority,' as Justice Breyer puts it,

'cannot wish this piracy example away by emphasizing that piracy takes place on the high seas [...]. That is because the robbery and murder that make up piracy do not normally take place in the water; they take place on a ship. And a ship is like land, in that it falls within the jurisdiction of the nation whose flag it flies.' (p. 4) 
And that would of course 'typically involve applying our law to acts taking place within the jurisdiction of another sovereign.' (pp. 4-5) The issue at stake here is, in other words, how to locate piracy in a normative space, that is, how space is signified with a certain meaning by being 'populated' (with pirates) in the course of legal arguments. Since pirates are granted a certain 'status' in ATS jurisprudence, locating their activity on another sovereign's territory would undermine the extraterritorial presumption argument. The majority's construction of piracy thus contributes to the plausibility of the whole (spatial) story. In this respect, the piracy issue is more than a mere-and somehow crude-sideshow.

\section{With Sufficient Force}

Through the decision on Kiobel the scope for future human rights suits against transnational private corporations is remarkably curtailed. These limits were established by way of an emphasis on the relation between corporative conduct and the territory of the United States. This 'spatial politics' of the Supreme Court, in turn, reserved a perhaps neoliberal space for private business where the US legal system may no longer interfere.

\section{'And even where the claims touch and concern the territory of the United States, they must do so with sufficient force to displace the presumption against extraterritorial application [...]. Corporations are often present in many countries, and it would reach too far to say that mere corporate presence suffices.' (p. 14)}

Touching and concerning territory with sufficient force, however, is setting a fluid criterion. What force is sufficient? And what does sufficiency mean against the backdrop of constructed territoriality, understood as a legal technology, not as physically given? In Kiobel, the judges did not only set a high hurdle for the sufficiency of force but were also critically engaged in the production of right that territory sufficiently to be touched. By demarcating territory in such a 'productive' way, a remarkable space has been left for private business. Thus, let me end with French sociologist Henri Lefebvre: 'There is a politics of space because space is political.'

\section{LICENSED UNDER CC BY NC ND}

SUGGESTED CITATION Liste, Philip: The Politics of Space: Kiobel v. Royal Dutch Petroleum, VerfBlog, 2013/4/22, http://verfassungsblog.de/the-politics-of-space-kiobel-v-royal-dutch-petroleum-2/. 